University of Wollongong

Research Online

Faculty of Engineering and Information

Faculty of Engineering and Information

Sciences - Papers: Part B

Sciences

2019

A method of uncertainty analysis for whole-life embodied carbon emissions (CO2-e) of building materials of a net-zero energy building in Australia

Mehdi Robati

University of Wollongong, University of New South Wales, mrobati@uow.edu.au

Daniel J. Daly

University of Wollongong, ddaly@uow.edu.au

Georgios Kokogiannakis

University of Wollongong, gkg@uow.edu.au

Follow this and additional works at: https://ro.uow.edu.au/eispapers1

Part of the Engineering Commons, and the Science and Technology Studies Commons

Research Online is the open access institutional repository for the University of Wollongong. For further information contact the UOW Library: research-pubs@uow.edu.au 


\title{
A method of uncertainty analysis for whole-life embodied carbon emissions (CO2-e) of building materials of a net-zero energy building in Australia
}

\begin{abstract}
The construction of new buildings requires the use of a substantial amount of materials, which have an associated embodied energy for manufacturing, transport, construction and end-of-life disposal. A number of inventories have been developed to collate the typical embodied energy or carbon emissions associated with different building materials and activities, and these can be used to quantify the environmental impacts of different construction methods. However, uncertainty exists in the estimation of embodied $\mathrm{CO} 2-\mathrm{e}$ emissions and other environmental impact results, due to i) inconsistencies in typical embodied carbon emissions values in inventories; ii) errors in estimations of material quantities; iii) assumptions regarding building lifetimes, and iv) errors in estimations of transport distances. This current study quantified the uncertainties associated with the calculation of lifetime CO2-e emissions in a case study net-zero, in terms of operational energy, educational building. This study examined the lifetime impacts of building materials for the building based on a detailed Life Cycle Assessment (LCA) that had been previously undertaken for this site. The study considered the 19 building materials which most heavily influenced the total, transport and recurring embodied carbon footprint of the building and a probability distribution was generated to represent the variability for each of the following uncertain parameters: Lifetime, Embodied CO2-e and transport distance over the building's life. Random sampling was used to generate input variables (1000 samples) based on a probability distribution of each uncertain parameter relative to the building materials. Through the use of a Monte Carlo simulation, the environmental impact for each construction material for a 50-year building lifetime was predicted. Unlike the conventional LCA approach, which provides a single deterministic value, cumulative Monte Carlo distribution curves were used to provide a range of embodied CO2-e emissions for each construction material, and the whole building, through the lifetime of the building. The obtained results revealed a distribution of the total embodied CO2-e of a building which ranged from 2951 tCO2-e to 5254 tCO2-e. This variation in the life cycle carbon emissions highlights the importance of considering an uncertainty analysis in the LCA analysis.
\end{abstract}

\section{Keywords}

whole-life, australia, method, energy, uncertainty, analysis, net-zero, materials, building, (co2-e), emissions, carbon, embodied

\section{Disciplines}

Engineering | Science and Technology Studies

\section{Publication Details}

Robati, M., Daly, D. \& Kokogiannakis, G. (2019). A method of uncertainty analysis for whole-life embodied carbon emissions (CO2-e) of building materials of a net-zero energy building in Australia. Journal of Cleaner Production, 225 541-553. 


\section{A method of uncertainty analysis for whole-life embodied carbon emissions $\left(\mathrm{CO}_{2}-\mathrm{e}\right)$ of} building materials of a net-zero energy building in Australia

\author{
Mehdi Robati $^{1,2}$, Daniel Daly ${ }^{1}$, Georgios Kokogiannakis ${ }^{1}$ \\ ${ }^{1}$ Sustainable Buildings Research Centre (SBRC), University of Wollongong, Australia \\ ${ }^{2}$ Faculty of Built Environment, University of New South Wales, Australia \\ *Corresponding author. Tel.: +61 420477662. \\ E-mail address: mr329@uowmail.edu.au (Mehdi Robati)
}

\section{Highlights}

- A net-zero educational building in Australia is considered for embodied $\mathrm{CO}_{2}$-e analysis.

- A method for building embodied $\mathrm{CO}_{2}$-e analysis based on Monte Carlo simulation was developed.

- Sensitivity analyses were employed to quantify uncertainties in building materials embodied $\mathrm{CO}_{2}$-e.

- A significant level of uncertainty is associated with four building materials.

\section{Abstract}

The construction of new buildings requires the use of a substantial amount of materials, which have an associated embodied energy for manufacturing, transport, construction and end-of-life disposal. A number of inventories have been developed to collate the typical embodied energy or carbon emissions associated with different building materials and activities, and these can be used to quantify the environmental impacts of different construction methods. However, uncertainty exists in the estimation of embodied $\mathrm{CO}_{2}$-e emissions and other environmental impact results, due to i) inconsistencies in typical embodied carbon emissions values in inventories; ii) errors in estimations of material quantities; iii) assumptions regarding building lifetimes, and iv) errors in estimations of transport distances.

This current study quantified the uncertainties associated with the calculation of lifetime $\mathrm{CO}_{2}$ e emissions in a case study net-zero, in terms of operational energy, educational building. This 
study examined the lifetime impacts of building materials for the building based on a detailed Life Cycle Assessment (LCA) that had been previously undertaken for this site. The study considered the 19 building materials which most heavily influenced the total, transport and recurring embodied carbon footprint of the building and a probability distribution was generated to represent the variability for each of the following uncertain parameters: Lifetime,

33 Embodied $\mathrm{CO}_{2}$-e and transport distance over the building's life. Random sampling was used to generate input variables (1000 samples) based on a probability distribution of each uncertain parameter relative to the building materials. Through the use of a Monte Carlo simulation, the environmental impact for each construction material for a 50-year building lifetime was predicted. Unlike the conventional LCA approach, which provides a single deterministic value, cumulative Monte Carlo distribution curves were used to provide a range of embodied $\mathrm{CO}_{2}$-e emissions for each construction material, and the whole building, through the lifetime of the building. The obtained results revealed a distribution of the total embodied $\mathrm{CO}_{2}$-e of a building which ranged from 2,951 $\mathrm{tCO}_{2}$-e to $5,254 \mathrm{tCO}_{2}$-e. This variation in the life cycle carbon emissions highlights the importance of considering an uncertainty analysis in the LCA analysis.

44 Keywords: Life cycle analysis, $\mathrm{CO}_{2}$-e emissions, Monte Carlo simulation, Uncertainty Analysis, net-zero educational building. 


\section{Introduction}

The construction industry is a major consumer of renewable and non-renewable natural resources. The construction of new buildings has substantial environmental costs; it is estimated that worldwide, buildings are responsible for the use of $40 \%$ of total primary energy, $40 \%$ of natural materials, $15 \%$ of the world's freshwater resources and $40-50 \%$ of greenhouse gas emissions (GHG) (Ding 2014; Lehne \& Preston 2018; Mokhlesian \& Holmén 2012; Ramesh et al. 2010). In Australia, the construction and demolition industry account for a significant amount of waste generated and disposed in a landfill (Crawford 2011; Yu et al. 2017).

The use of appropriate building materials to minimise the industry's environmental impact has received increasing research attention. A holistic approach to the selection of sustainable building materials should consider the life cycle of a building, including building performance and embodied energy (Berge 2009; Franzoni 2011; Hester et al. 2018; Le, Khoa N. et al. 2018).

60 The life cycle of a building material includes the extraction of raw materials, manufacturing processes, transportation to the construction site, construction processes, the operational phase, and the end of life recycling and potential for reuse (Ding 2014).

As buildings become more energy efficient, the operational phase of a life cycle assessment will make an increasingly smaller contribution to the total environmental impact, while material selection will become relatively more important (Davies \& Trabucco 2018; Hammad et al. 2018; Oldfield 2012). However, selecting sustainable building materials is a challenging task (Saghafi \& Teshnizi 2011; Tam et al. 2018), because it requires an analysis of building materials embodied environmental impact at all stages of the life cycle, as well as the energy performance of the material as part of the operation of buildings. This is an ongoing area of 
research due to a large number of variables and the uncertainty involved in the assessment process (Hester et al. 2018; Paolo et al. 2018).

Several studies attempted to quantify the risks associated with the whole-life environmental performance of buildings (Beltran et al. 2016; Crawford 2011; Dixit et al. 2010; Mendoza Beltran, M. A. et al. 2018). For instance, Mendoza Beltran, M. A. et al. (2018) categorised those risks into the uncertainties associated with methodological choice, model uncertainty, lack of knowledge on system behaviour, and simplification characteristics of LCA (inclusion and exclusion in the system boundaries). Meanwhile, a review by Pomponi and Moncaster (2016) showed that different methods and techniques have been developed to analyse uncertainties and variations in LCA including: stochastic modelling (Hong et al. 2017; Miller et al. 2013), fuzzy theory (Egilmez et al. 2016), possibility theory (André \& Lopes 2012), Tylor series expansions (Hoxha et al. 2014), data quality indicators (Wang \& Shen 2013) as well as expert judgements and/or combinations of the methods. Despite the previous studies for addressing the uncertainties and variabilities associated with LCA study, there is still a significant gap in current research related to the uncertainty with the embodied energy of materials in the processing, manufacturing, and construction of low operational energy buildings, relative to operational impacts and uncertainty.

This study aimed to determine the uncertainties associated with the life cycle assessment of a net-zero energy educational building in Australia. Section 2 summarises uncertainty associated with lifetime $\mathrm{CO}_{2}$-e emissions analysis in the building industry. Section 3 describes the methodological approach used to analyse the uncertainty associated with life cycleCO $\mathrm{CO}_{2}-\mathrm{e}$

91 emissions of the net-zero energy educational building of this study. Section 4 provides results

92 on the embodied $\mathrm{CO}_{2}$-e emissions intensity for different building materials and products, 
93 followed by a discussion of the key role of four important materials selected in the overall

94 embodied $\mathrm{CO}_{2}$-e emissions of the case study building.

114 The European Standard EN15978 (EN15978 2011) has proposed a number of methods for

\section{Life cycle assessment in buildings}

Life cycle analysis is a method for identifying and evaluating the environmental aspects of a product during its life (ISO14040 2006); this method assesses the impacts from the materials used and energy released by the system into the environment. Applying a life cycle analysis to the building sector is a particularly complex life cycle analysis problem (Ortiz et al. 2009; Taborianski \& Prado 2004) due in part to the complexity, size, and intensive use of natural resources in all stages of a building's life (Sharma et al. 2011). The following factors introduce further complexity to LCA in this sector:

- Buildings have a particularly long lifetime, often more than half a century, so it is difficult to predict the whole of lifetime behaviour of the project from cradle-to-grave (Cabeza et al. 2014; Paolo et al. 2018);

- During the lifetime of a project, the building may undergo many changes in terms of form and function, changes which can be as significant as the original construction (Stephan \& Crawford 2014). Future changes can potentially be considered at an early stage of design to minimise the environmental effects of changes (Crawford 2011);

- There are many stakeholders and shareholders involved in the building industry. Stakeholders comprise professionals and non-professional who are involved in the conceptions, design, constructions, post constructions and end of life of projects (Oke \& Aigbavboa 2017).

assessing the environmental performance of buildings. The standard calculation method 
116 involves the following four stages in an LCA of buildings: the product stage (raw materials

117 extraction, transportation and manufacturing); the construction process (transportation to the

118 site, construction and installation process); the use stage (usage, maintenance, repair,

119 replacement and refurbishment), and the end of life (deconstruction, demolition, transportation,

120 waste processing and disposal). The system boundary includes the extraction of raw materials,

121 production processes, transportation, and use and disposal.

122 A number of studies have found that the use stage (operational energy) accounts for $80 \%$ to $12385 \%$ of the life cycle energy consumption in buildings (Richman et al. 2009; Robati et al. 2017;

124 Sharma et al. 2011). The energy inputs for the production of building products, the extraction 125 and processing of raw materials, and manufacturing and transportation to construction sites are 126 responsible for the remaining $15 \%$ to $20 \%$ of whole life cycle energy usage of a building 127 (Asdrubali et al. 2013). The contribution made by construction activities, and final demolition 128 and disposal at the end of life is deemed negligible, at level of approximately $1 \%$ (Ruuska \& 129 Häkkinen 2015; Sartori \& Hestnes 2007).

130 To understand the role that building materials have on an energy efficient design; the 131 operational and embodied energy implications of building design options must be investigated.

132 Since the operational energy offers the most opportunities for energy efficiency, the majority 133 of previous research has focused on reducing it, and less research has been done on minimising 134 the impacts from all the stages of a building's life cycle.

135 Existing literature has highlighted the significance of building materials and embodied energy 136 in a lifetime energy analysis of buildings (Akbarnezhad \& Xiao 2017; Catherine et al. 2016;

137 Tecchio et al. 2018). An appropriate choice of construction and building materials can reduce 138 the embodied energy and embodied $\mathrm{CO}_{2}$-e emissions by $17 \%$ and $30 \%$, respectively, over the 
139 lifetime of buildings (González \& García Navarro 2006; Thormark 2006). Asif et al. (2007)

140 studied the life cycle embodied energy and the emissions associated with five commonly used

141 materials (glass, aluminium, wood, ceramic tiles, and concrete) in a Scottish residential house.

142 Concrete was responsible for $60 \%$ of the total embodied energy in those buildings. Similarly,

143 Ximenes and Grant (2013) used the LCA method to determine the GHG emissions associated

144 with several building materials in Australia and found that structural elements consisting of 145 concrete and bricks are responsible for up to $31 \%$ and $17 \%$ of the total greenhouse gases

146 impact, respectively. The authors also found that the use of timber in the sub-floor resulted in

147 between $31 \%$ and 56\% reductions in embodied GHG emissions. Aye et al. (2012) undertook

148 LCA on three forms of common Australian building constructions and showed that steel

149 structured buildings reduce the consumption of material by almost $78 \%$ by mass compared to

150 a concrete structure. However, the steel structure resulted in a $50 \%$ increase in embodied

151 energy compared to the concrete structure. They concluded that an efficient use of materials

152 could result in energy savings of up to $81 \%$ of embodied energy, and $51 \%$ of the mass of 153 materials.

154 A number of previous studies identified variations and inconsistencies in embodied energy estimation methodologies (Crawford 2013; Dixit et al. 2010; Huang et al. 2010; Langston \&

156 Langston 2008; Robati et al. 2016). Dixit et al. (2010) found these sources of uncertainty to be:

157 variations in the method of analysis used in each assessment; different system boundaries; and 158 the quality of data sources and input in the calculation of upstream processes. Accordingly, it 159 is important to use methods to quantify the uncertainties associated with the LCA of buildings 160 and construction materials. This study, therefore, aimed to quantify the uncertainty associated 161 with the whole-life embodied carbon emissions of a net-zero energy case study building. The 
analysis of these uncertainties for the case study building will demonstrate the importance of uncertainty analysis within life cycle assessment.

\section{Methodology}

165 The uncertainty associated with whole-life embodied carbon impact was assessed for a case166 study net-zero operational energy building, the University of Wollongong's Sustainable 167 Buildings Research Centre (SBRC). The SBRC building is a 6 Star Green Star building (GBCA 168 2017), and can be considered as a best practice building for sustainability in Australia, both in terms of minimising operational energy consumption, and minimising embodied energy through design and material selection. A brief characterises of SBRC building is summarised

171 in Table 1.

172 Table 1 a brief characterises of SBRC building.

\begin{tabular}{|c|l|}
\hline \multirow{4}{*}{ Floor area } & $-1700 \mathrm{~m}^{2}$ of office and laboratory spaces \\
& $-900 \mathrm{~m}^{2}$ of industrial research high-bay \\
& $-360 \mathrm{~m}^{2}$ of roof-top testing space \\
& $-1700 \mathrm{~m}^{2}$ of external breakout space
\end{tabular}

173

174 The SBRC building was selected as a case study because it represented a critical case where

175 the operational energy is minimised. The uncertainty associated with whole-life embodied 176 carbon emissions analysis for this building was therefore anticipated to be relatively significant compared to typical construction. The boundary of this study considered the embodied $\mathrm{CO}_{2}-\mathrm{e}$ 

and at the end life activities (as shown in Figure 1).

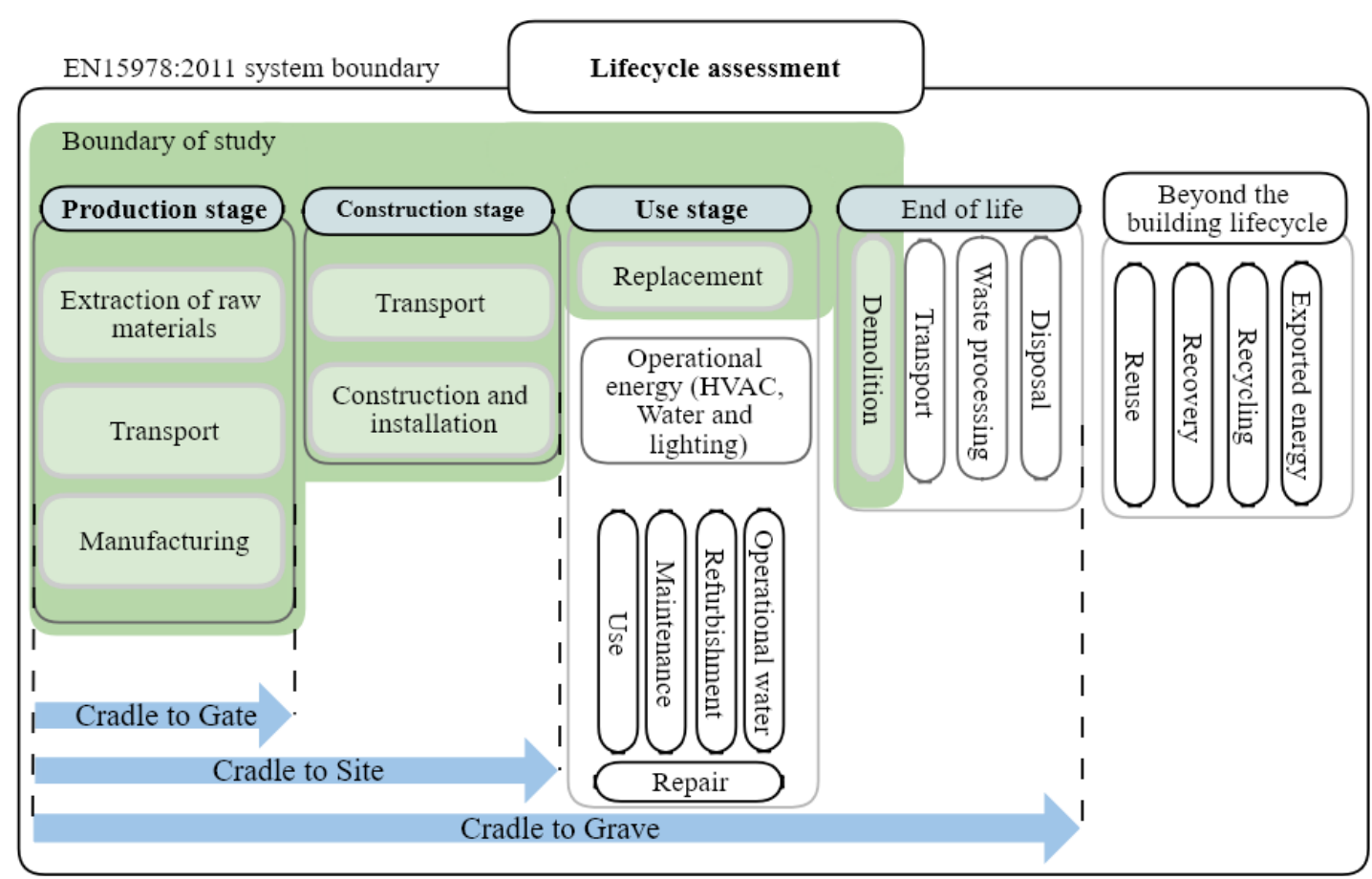

180

Figure 1. Boundary of study (EN15978 2011)

We employed a sensitivity-based method to determine the ranges of dependent parameters by considering the uncertainties associated with the independent parameters (the embodied carbon emissions of the building and the building materials are summarised in section 4). The Input parameters were: Material quantities, lifespan, embodied carbon emissions and transport distances and are summarised in Table 2. Sensitivity analysis methods can be grouped into a screening, local and global methods (Heiselberg et al. 2009). We undertook a global sensitivity and uncertainty analysis using the Monte Carlo simulation method. Monte Carlo is a statistical method that uses random values from input parameters and presents a distribution for the output parameter, and has been previously employed in numerous studies, e.g.(Bisinella et al. 2016; 
192 Bojacá \& Schrevens 2010; Grant et al. 2016; Mendoza Beltran, Angelica et al. 2018). Global

193

194

195

196

197

198

199

200

201

202

203

204

205

206

207

208

209

210

211

212

213

214 sensitivity analysis methods have the advantage that all parameters are varied at the same time, and the effect of input parameter range and probability density function are considered (Bisinella et al. 2016; Silva \& Ghisi 2014).

This study consisted of five major steps, namely:

1) Identify the relevant input parameters and define their probability density functions; The input parameters consist of the top 19 building materials which most heavily influenced the primary (production stage), transport and recurring embodied carbon footprint of the building (material quantities were extracted from a previously undertaken study for this site).

2) Define the appropriate probability density function of the input parameters using the embodied $\mathrm{CO}_{2}$-e emissions, lifetime and the transport distance extracted from published literature;

3) Perform a random sampling, using, for example, Microsoft Excel's normal distribution function: the input parameters (embodied $\mathrm{CO}_{2}$-e emissions, lifetime and transport distance) associated with each building material (Table 2) were randomly generated 1000 times to achieve more accurate results (Inyim et al. 2016).

4) Perform an uncertainty analysis: for each 1000 sample data, Equation 1 was used to generate the probability distribution of all the input parameters. The total result presents the global uncertainty analysis associated with the building.

5) Perform a sensitivity analysis to quantify the magnitude of the change in the estimated embodied $\mathrm{CO}_{2}$-e emissions of the building and building materials. In this last step, the range of embodied carbon emissions for each construction materials was quantified and 

overall $\mathrm{CO}_{2}$-e emissions of the building.

219 Table 2 quantity and assumed distributions of analysed parameters.

\begin{tabular}{|c|c|c|c|c|c|c|c|c|c|}
\hline \multirow{3}{*}{ 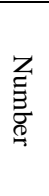 } & \multirow{3}{*}{ Parameter (i) } & \multirow{3}{*}{ Unit } & \multirow{3}{*}{ Quantity } & \multicolumn{6}{|c|}{ Distribution } \\
\hline & & & & \multicolumn{2}{|c|}{ Lifetime (years) ${ }^{\mathrm{I}}$} & \multicolumn{2}{|c|}{$\begin{array}{c}\text { Embodied } \mathrm{CO}_{2} \text {-e emissions } \\
(\mathrm{kg} / \mathrm{unit} \text { of material })^{\mathrm{II}}\end{array}$} & \multicolumn{2}{|c|}{ Distance $(\mathrm{km})^{\mathrm{III}}$} \\
\hline & & & & Mean & SD & Mean & SD & Mean & SD \\
\hline 1 & Solar PV Panels (Polycrystalline) & $\mathrm{m}^{2}$ & 983 & 22.50 & 2.08 & 249.00 & 0.00 & 67.32 & 55.77 \\
\hline 2 & $\begin{array}{c}\text { Windows (Aluminium Framed; } \\
\text { Double Glaze) }\end{array}$ & $\mathrm{m}^{2}$ & 1,017 & 25.00 & 10.80 & 245.12 & 34.12 & 150.00 & 72.24 \\
\hline 3 & $\begin{array}{l}\text { Concrete (Structural; } 40 \\
\quad \text { MPa; } 60 \% \text { BFS*) }\end{array}$ & $\mathrm{m}^{3}$ & 461 & 135.00 & 60.20 & 398.39 & 80.60 & 12.00 & 7.07 \\
\hline 4 & $\begin{array}{c}\text { Concrete (Walls, floor topping } 40 \\
\text { MPa,30\% BFS) }\end{array}$ & $\mathrm{m}^{3}$ & 370 & 135.00 & 60.20 & 300.80 & 158.53 & 12.00 & 7.07 \\
\hline 5 & Steel (General) & $\mathrm{kg}$ & 55,091 & 115.90 & 42.23 & 1.45 & 1.14 & 8.72 & 4.95 \\
\hline 6 & Steel (Hot Rolled & $\mathrm{kg}$ & 56,362 & 105.00 & 10.00 & 1.18 & 0.98 & 8.72 & 4.95 \\
\hline 7 & $\begin{array}{l}\text { Insulation (Loose Fill; Cellulose } \\
\text { Fibre) }\end{array}$ & $\mathrm{m} 3$ & 390 & 22.50 & 2.88 & 335.22 & 0.00 & 108.00 & 0.00 \\
\hline 8 & Aluminium & $\mathrm{kg}$ & 16,838 & 69.38 & 58.64 & 13.10 & 5.79 & 9.50 & 7.56 \\
\hline 9 & $\begin{array}{l}\text { Windows with Aluminium } \\
\text { Framed and Single Glaze }\end{array}$ & $\mathrm{m}^{2}$ & 308 & 42.40 & 28.21 & 202.61 & 0.00 & 2.04 & 1.13 \\
\hline 10 & $\begin{array}{l}\text { Plaster and Gypsum Derived } \\
\text { Products }\end{array}$ & $\mathrm{m}^{2}$ & 3,488 & 46.25 & 21.74 & 5.36 & 4.63 & 4.20 & 2.86 \\
\hline 11 & Bulk Aggregates Sands and Soils & $\mathrm{m}^{3}$ & 177 & 87.00 & 83.56 & 95.05 & 127.54 & 7.00 & 2.91 \\
\hline 12 & Bricks, Blocks and Pavers & $\mathrm{kg}$ & 257,915 & 150.00 & 39.52 & 0.31 & 0.25 & 19.50 & 14.72 \\
\hline 13 & Rubber, Synthetic & $\mathrm{kg}$ & 3,434 & 47.22 & 40.31 & 3.43 & 1.08 & 5.50 & 2.38 \\
\hline 14 & Plastics (HDPE**) & $\mathrm{m}^{3}$ & 2.80 & 116.66 & 54.48 & $6,681.12$ & $1,615.28$ & 5.15 & 4.55 \\
\hline 15 & Carpets and Floor Coverings & $\mathrm{m}^{2}$ & 622 & 10 & 3.80 & 22.54 & 12.36 & 6.98 & 6.39 \\
\hline 16 & Plastics (Polycarbonate) & $\mathrm{kg}$ & 991 & 18.75 & 2.98 & 17.45 & 16.19 & 5.15 & 4.55 \\
\hline 17 & $\begin{array}{l}\text { Electrical Goods (Electrical } \\
\text { Equipment) }\end{array}$ & \# & 40,000 & 10.00 & 1.58 & 0.41 & 0.00 & 5.15 & 4.55 \\
\hline 18 & Plastics (General) & $\mathrm{kg}$ & 1,814 & 40.00 & 26.55 & 5.93 & 2.93 & 5.15 & 4.55 \\
\hline 19 & Electrical Goods (Inverter) & $\mathrm{kg}$ & 271 & 20.00 & 4.08 & 51.54 & 14.05 & 5.15 & 4.55 \\
\hline
\end{tabular}

References:

I.Materials lifetime (Cabeza et al. 2014; Ding 2004; Ding 2008; eTool 2014; Furuta et al. 2014; Thormark 2006);

II.Embodied $\mathrm{CO}_{2}$-e emissions (Alcorn 2003; BPIC 2014; Crawford 2011; Hammond et al. 2011; Moussavi Nadoushani \& Akbarnezhad 2015; Robati et al. 2016); III.Online mapping tools.

*BFS: Blast Furnace Slag $\mid * *$ HDPE: High Density Polyethylene

221 The overall embodied $\mathrm{CO}_{2}$-e emissions was calculated by adding the magnitude of each

222 parameter through the use of Equation (1). Equation (1) represents lifetime (Cradle to Grave) 11 
environmental impacts (embodied $\mathrm{CO}_{2}$-e emissions) associated with selection of the building materials which was adopted from previous studies (Akbarnezhad \& Xiao 2017; Crawford 2011).

226

$$
T_{C O_{2}-e}=\sum_{i=1}^{n=19}\left(\frac{L_{t}}{L_{i}} \times\left(\left(Q_{i} \times I_{i}\right)+\left(\frac{Q_{i}}{C_{t}} \times I_{t} \times D_{i}\right)\right)\right)
$$

Where:

- $\mathrm{T}_{\mathrm{CO}_{2}-e}$ is the total embodied $\mathrm{CO}_{2}$-e emissions of the building ( $\mathrm{kg} \mathrm{CO}_{2}$-e emissions); This study considers the impacts of the top 19 materials ranked in terms of quantity used in the case study building $(\mathrm{n}=19)$.

- $\quad i$ is the building material number as shown in Table 2;

- $\quad L_{t}$ represents the total lifetime of the building, assumed to be 50 years (AS3600 2009);

- $L_{i}$ is the lifetime associated to the $\mathrm{i}^{\text {th }}$ building material (number of years); for a material's lifespan higher than 50 years (such as concrete, steel reinformance, timber), the lifetime ratio $\left(\frac{L_{t}}{L_{i}}\right)$ is equal to 1 ;

- $Q_{i}$ represents the quantity of the $i$ th building material (based on Table 2);

- $I_{i}$ is the embodied $\mathrm{CO}_{2}$-e emissions associated with the $\mathrm{i}^{\text {th }}$ building material $\left(\mathrm{kg} \mathrm{CO}_{2}\right.$-e /unit of material);

- $C_{t}$ is related to the truck capacity, which can carry a $20 \mathrm{ft}$ container (volume $39 \mathrm{~m}^{3}$ );

- $I_{t}$ is the embodied $\mathrm{CO}_{2}$-e emissions associated with the truck used to transport materials (excluding concrete). This is assumed here as $0.07155\left(\mathrm{~kg} \mathrm{CO}_{2}\right.$-e /tonne per km) (Moussavi Nadoushani \& Akbarnezhad 2015).

- $D_{i}$ is the travelling distance the $\mathrm{i}^{\text {th }}$ building material (Table 2) was transported from the supplier to the counstruction site $(\mathrm{km})$. 
246 Figure 2 summarises the workflow and the methodology used to quantify the uncertainty

247 associated with a lifetime environmental assessment of the SBRC building. 


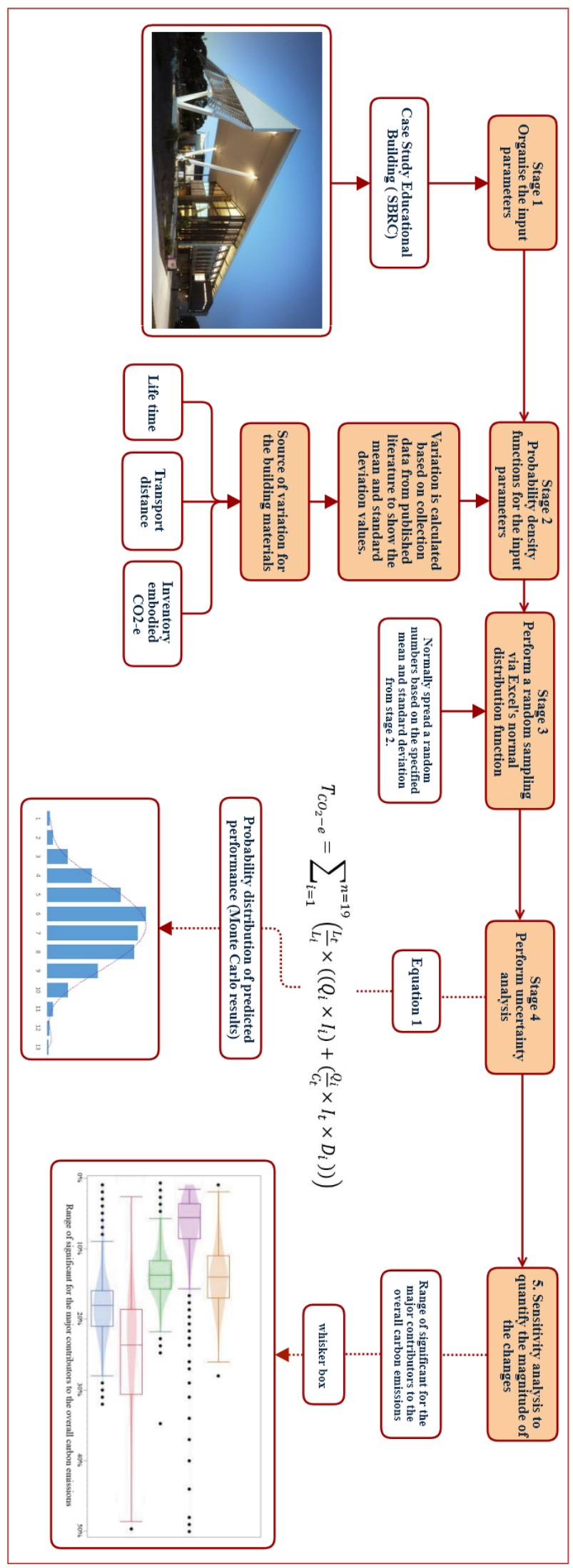

249 Figure 2. The workflow and methodology used in this study 
250 Stage 2 of methodology considers the variations associated with the lifetime of materials, 251 embodied $\mathrm{CO}_{2}$-e emissions, and the travel distance. The amount of variation is calculated based

252 on collecting data from published literature to represent the mean and standard deviation 253 values.

254 The spread of random numbers in stage 3 was determined by the specified mean and the specified standard deviation of each input parameter from stage 2 (as shown in Table 2). A normal distribution is recommended for modelling the variations associated with each input variable because the maximum and minimum $\mathrm{CO}_{2}$-e emissions values were not clear enough to define them (Inyim et al. 2016; Peña-Mora et al. 2009). It was therefore assumed that all the

259 parameters (lifetime, embodied $\mathrm{CO}_{2}$-e emissions and travel distance) associated with the building materials are distributed normally along the standard deviation (SD). So, the lifetime,

261 the embodied $\mathrm{CO}_{2}$-e emissions of materials, and the travel distance between the material 262 suppliers to the construction site are distributed separately because each variable comes from 263 different sources of data. A normal distribution is used because when that other distribution 264 (rectangular, triangular) is combined it often yields a net distribution which is close to normal 265 (Farrance \& Frenkel 2014).

266 An existing life cycle assessment for the case study building had been completed prior to the 267 current study, and the result presented a single deterministic embodied $\mathrm{CO}_{2}$-e emissions value 268 for the building (Cradle to Grave). This study extended the existing LCA to include a risk analysis to quantify uncertainties associated with the calculation of $\mathrm{CO}_{2}$-e emissions. The material quantity from the existing LCA was used for the calculation, as they were based on

271 as-built documentation; however, it is acknowledged that this assumption could be an 272 additional source of uncertainty which was unexplored in this study. The system boundary of 273 the existing LCA study was the same as the current study in this paper (Figure 1). Stage 2 of 15 
methodology considers the variations associated with the lifetime of materials, embodied $\mathrm{CO}_{2}$ e emissions, and the travel distance. The amount of variation is calculated based on collecting data from published literature to represent the mean and standard deviation values for each of

277 the top 19 dominantly used materials by quantity in the building. The variations in the 278 material's lifespan came from published literature (Cabeza et al. 2014; Ding 2004; Ding 2008; 279 eTool 2014; Furuta et al. 2014; Thormark 2006). The embodied $\mathrm{CO}_{2}$-e emissions coefficient associated with the building materials came from six inventory databases: BPIC (BPIC 2014), ICE (Hammond et al. 2011), eTools (eTool 2014), Alcon (Alcorn 2003), AusLCI (AusLCI 2016), Crawford (2011), and other published literature (Moussavi Nadoushani \& Akbarnezhad 2015; Robati et al. 2016). The mean travel distance value from the potential manufacturing companies to the site was measured using online mapping tools (Poinssot et al. 2014; Robati et al. 2018). The values assumed for the study parameters (top 19 building materials) are included in Table 2.

One of the considerable limitations of this study is the inability to precisely determine the distributional form and number of samples in the Monte Carlo analysis. Also, Monte Carlo analysis demands more data (Miller et al. 2013), and there is not a certain agreement on the minimum size of samples (iterations) that are required to be carried out (Pomponi et al. 2017). Increasing the sample size adds to computational time and complexity of the analysis(Lloyd \& 292 Ries 2007). By considering these limitations, we used 1000 sample size (Gantner et al. 2018;

293 Inyim et al. 2016) by using a selected combination of the inputs which were taken from several studies (as outlined in Table 2). Besides these limitations, Monte Carlo analysis still is the most widely implemented method to assess uncertainties associated with various LCA studies (Hong et al. 2018; Pomponi et al. 2017). Another limitation relates to the quantity of the building

297 materials extracted from an existing LCA data, which based on as-built documentation. 


\section{Results and discussion}

299 This section presents the results of the global uncertainty and sensitivity analysis for the LCA

300 of the whole building, and a targeted consideration of parameters which have a particularly

301 large influence on the LCA results.

\section{$302 \quad 4.1$ Uncertainty for the whole-life $\mathrm{CO}_{2}$-e emissions analysis}

303 The results of the Monte Carlo uncertainty analysis that were generated using Equation 1 are

304 displayed in Figure 3. The results were generated from 1000 iterations (as recommended by 305 Inyim et al. (2016)) of each parameter generated independently using normal distributions with 306 the mean and the standard deviations from Table 2. For instance, Figure 4 presents the

307 variations associated with the embodied $\mathrm{CO}_{2}$-e emissions coefficients for two grades of 308 concrete (N32 and N40); for concrete N32 and N40, the standard deviation and mean values 309 are obtained from 203 and 175 datasets, respectively. By summing up the embodied $\mathrm{CO}_{2}$-e

310 emissions of the building materials, the total embodied $\mathrm{CO}_{2}-\mathrm{e}$ emissions of the SBRC building 311 was calculated. 


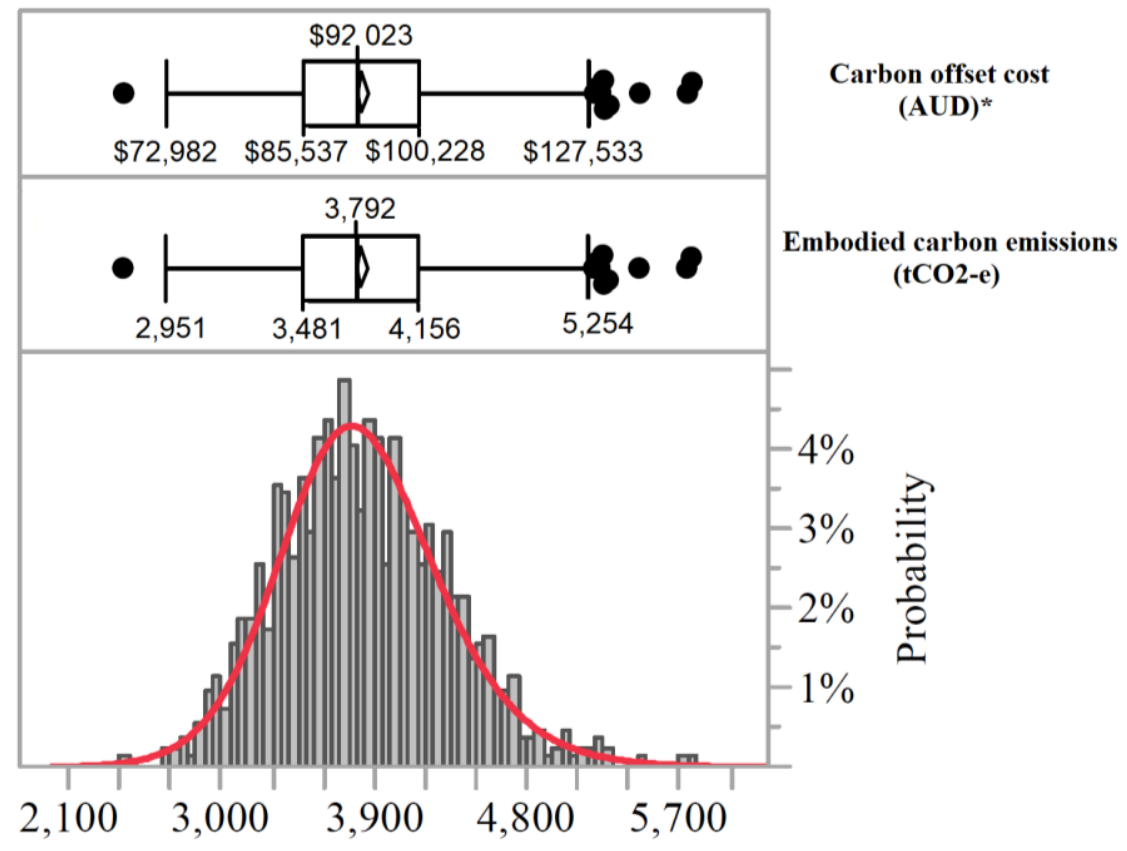

Embodied CO2-e (tonne)

$313 *$ The price of $\mathrm{CO}_{2}$-e emissions is based on the Robati et al. (2018) method and the Australia Emissions Trading 314 Scheme (Combet 2012).

315 Figure 3. Probability distribution of LCA from global uncertainty analysis sampling

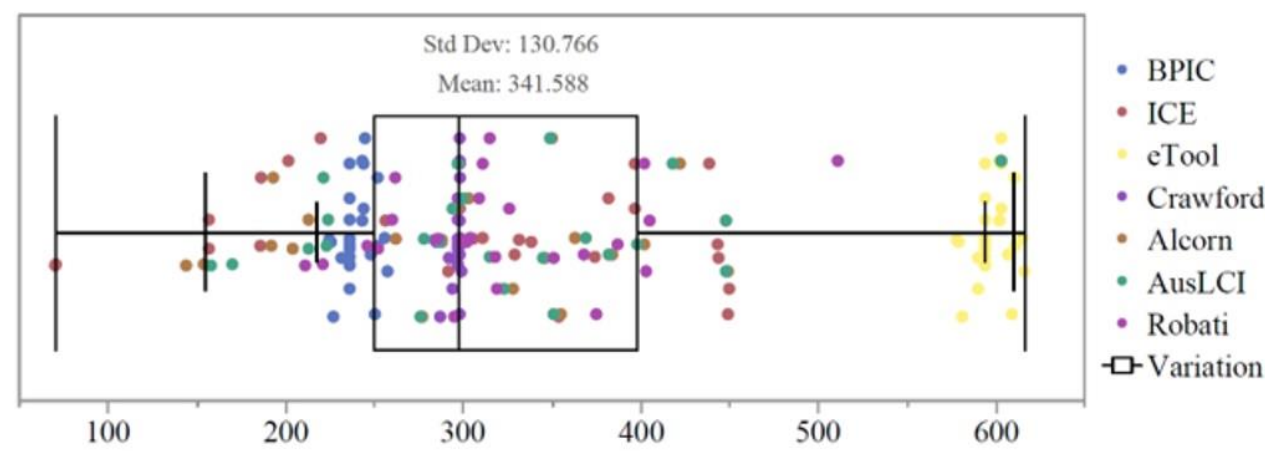

a.Embodied $\mathrm{CO}_{2}$-e across inventory databases and literature for $40 \mathrm{MPa}$ concrete $\left(\mathrm{kg} / \mathrm{m}^{3}\right)$

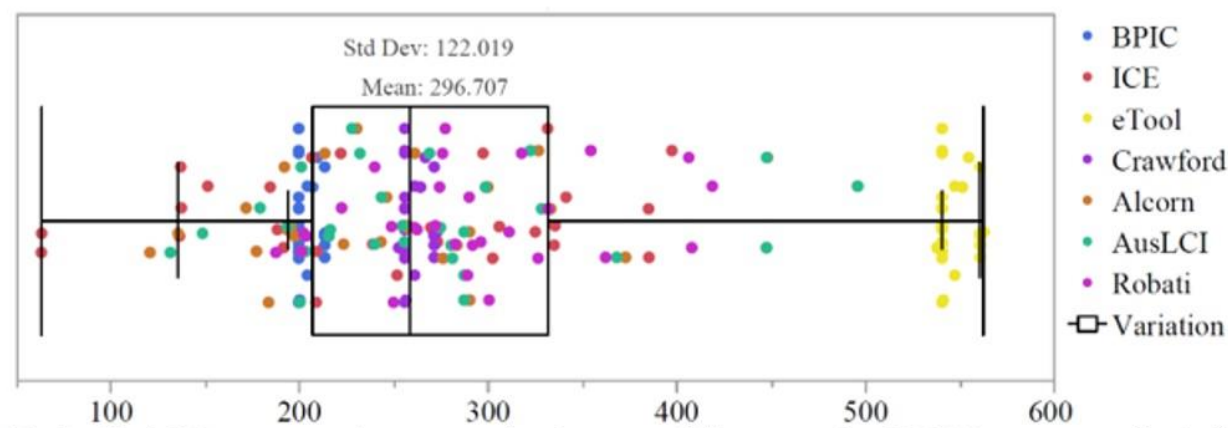

b.Embodied $\mathrm{CO}_{2}$-e across inventory databases and literature for $32 \mathrm{MPa}$ concrete $\left(\mathrm{kg} / \mathrm{m}^{3}\right)$

318 Figure 4. Embodied CO2-e emissions variations for two grades of concrete (a.N32 and b.N40) 
Figure 3 summarises the global uncertainties associated with the whole-life carbon emissions analysis results of the SBRC building. The distribution of the total embodied $\mathrm{CO}_{2}$-e was found between $2,951 \mathrm{tCO}_{2}$-e to $5,254 \mathrm{tCO}_{2}$-e using a range of reasonable inputs taken from previous studies. The mean value was found to be 3,828 $\mathrm{tCO}_{2}$-e (median value was $3,792 \mathrm{tCO}_{2}$-e), with a standard deviation of $502 \mathrm{tCO}_{2}$-e. Accordingly, the carbon offset cost (voluntary market in Australia) to compensate the carbon emissions for the low carbon analysis would be $\$ 72,982$; while, the high value offset would be $\$ 127,533$ by considering a $95 \%$ confident interval (as shown in Figure 3). This variation in the embodied emissions and carbon offset cost highlights the importance of considering an uncertainty analysis in the LCA analysis.

The relative importance of the analysed materials is shown in Figure 5. It can be seen that the windows, PV system and concrete as a structural material have the largest mean impact on total embodied CO2-e emissions of the building. The top six materials, each contributing greater than $5 \%$ of the total mean embodied carbon emissions, were responsible for $75 \%$ of the total embodied $\mathrm{CO}_{2}$-e emissions.

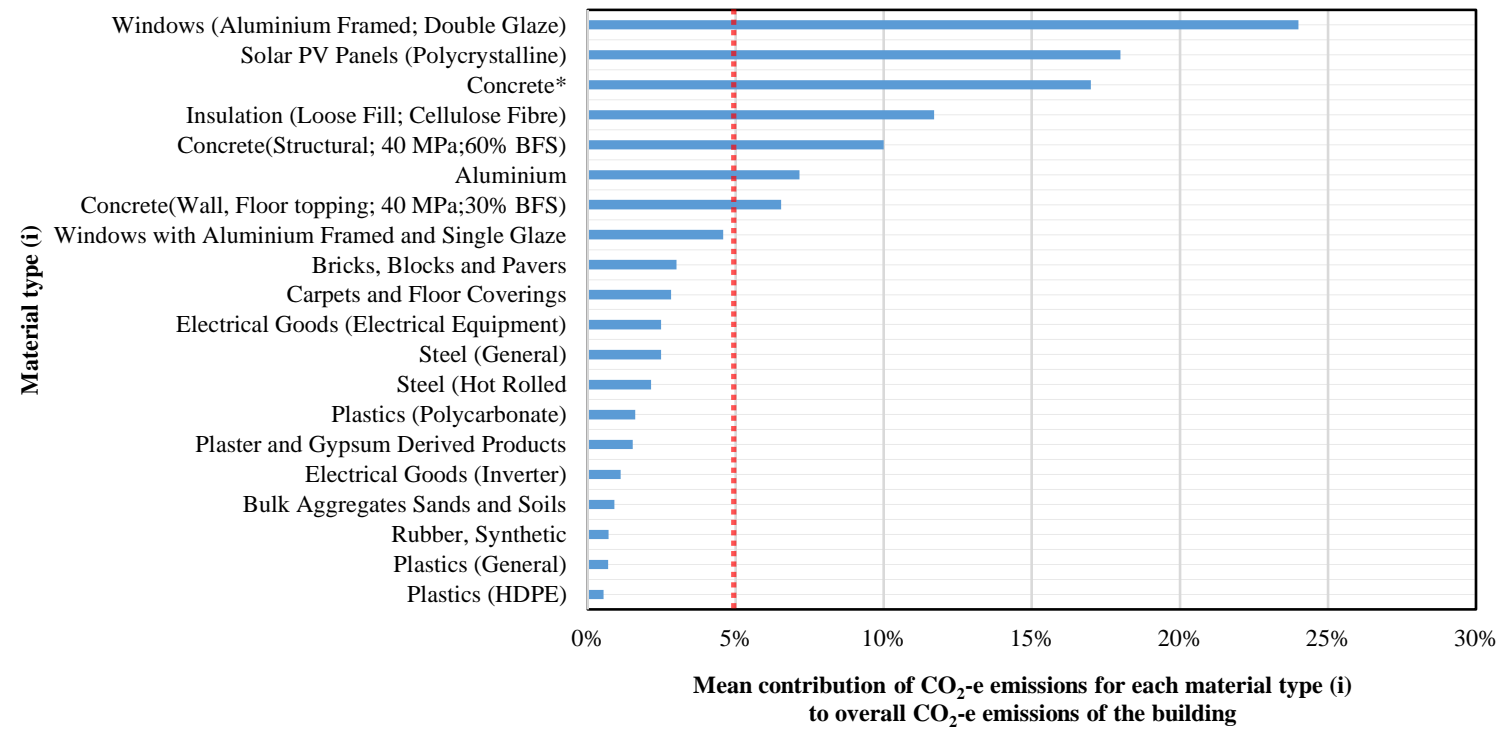

* represents the combinations of both types of concrete (material number 3 and 4 in Table 2). BFS: Blast Furnace Slag | HDPE: High Density Polyethylene. 
Further analysis revealed the range of uncertainty associated with the construction materials that have the highest contributions in terms of carbon emissions as shown in Figure 6. It can be seen that there is a particularly significant level of uncertainty associated with Solar PV

340 Panels, Windows, Insulation, Aluminium and Concrete. These sources of uncertainty

341 associated with these materials are explored in the following sections.

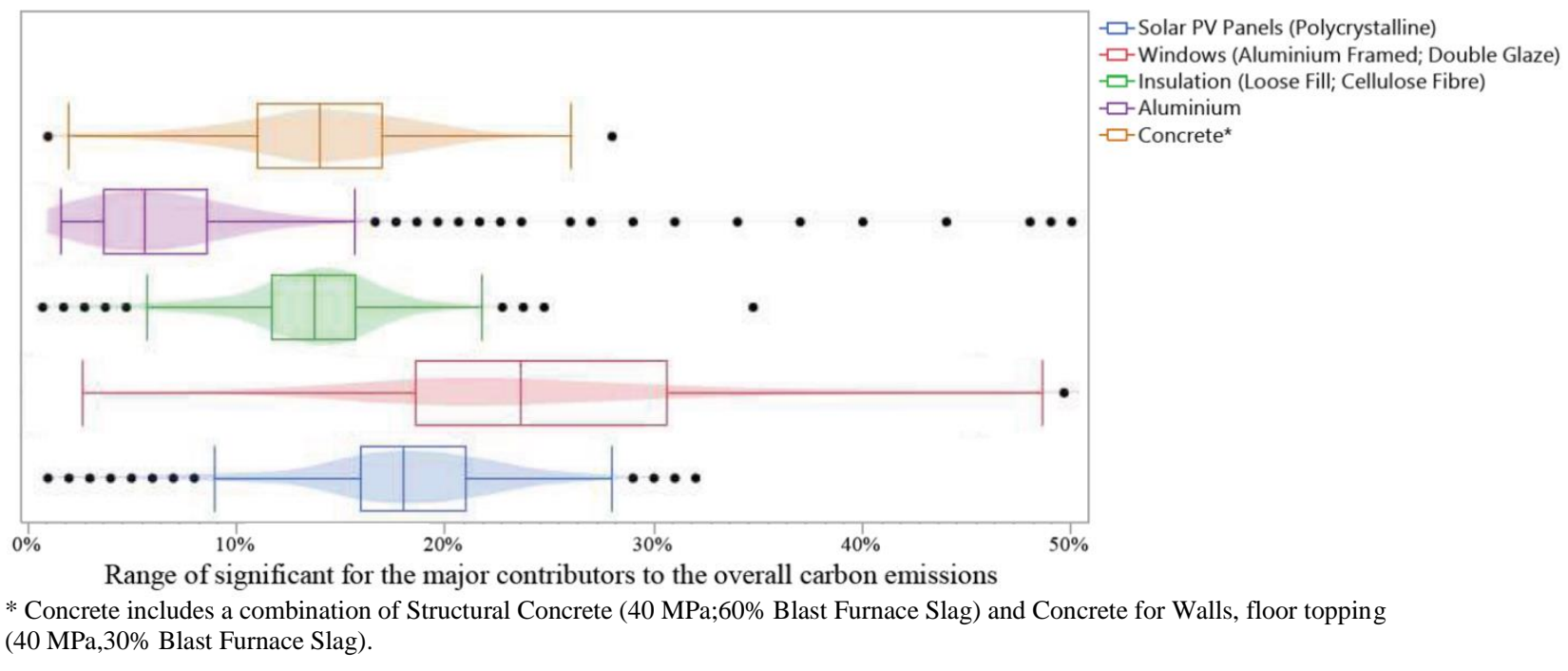

Figure 6. Range of significant for the major contributors to the overall carbon emissions.

\section{$346 \quad 4.2$ Uncertainty associated with Aluminium, insulation and windows}

347 Aluminium (general use), windows (double glazed and aluminium framed) and insulation

348 materials had a high impact on total embodied $\mathrm{CO}_{2}$-e emissions of the building. The mean

349 percentage contribution to the overall embodied $\mathrm{CO}_{2}$-e emissions of the building was $7 \%$ for 350 aluminium, $12 \%$ for insulation and $24 \%$ for windows (Figure 7 ).

351 The embodied $\mathrm{CO}_{2}$-e emissions contribution associated with aluminium ranged from $1 \%$ to $15 \%$ of the overall embodied $\mathrm{CO}_{2}$-e emissions from the building when assuming a $95 \%$ confidence interval. The respective embodied $\mathrm{CO}_{2}$-e emissions related to the insulation 
materials varied from $6 \%$ to $22 \%$, while for the aluminium double-glazed windows, they varied from $3 \%$ to $46 \%$.

356 For these materials, the uncertainties mainly result from the variations in embodied $\mathrm{CO}_{2}-\mathrm{e}$

357 emissions coefficient as proposed by different inventory databases. For instance, the amount

358 of the embodied $\mathrm{CO}_{2}$-e emissions for aluminium, which is a material with high energy content,

359 ranged from 8 to $22.8\left(\mathrm{~kg} \mathrm{CO}_{2}-\mathrm{e} / \mathrm{kg}\right)$ in the existing databases. The respective embodied $\mathrm{CO}_{2-}$

360 e emissions associated with insulation changes from 0.63 to $1.05\left(\mathrm{~kg} \mathrm{CO}_{2}-\mathrm{e} / \mathrm{kg}\right)$; for the

361 windows, the carbon emissions factor was sourced as 216 to $279\left(\mathrm{~kg} \mathrm{CO}_{2}-\mathrm{e}\right) / \mathrm{m}^{2}$ (eTool 2014;

362 Hammond et al. 2011).

363 Additionally, it was found that the short lifetime for insulation materials and windows

364 contributed to $23 \%$ and $38 \%$ of their embodied carbon emissions, respectively. Similarly, the

365 shipping distance constitutes $4 \%$ of the windows and $5 \%$ the insulation materials total

366 embodied carbon emissions.

367 As both, insulation and windows, have a lower lifetime than other materials, they required more

368 maintenance and refurbishments over the lifetime of the building. Moreover, the type of 369 shipping and transport distance have a significant impact on intensity of embodied $\mathrm{CO}_{2}$-e 370 emissions of the windows (Dowdell et al. 2016; Macintosh 2007). 


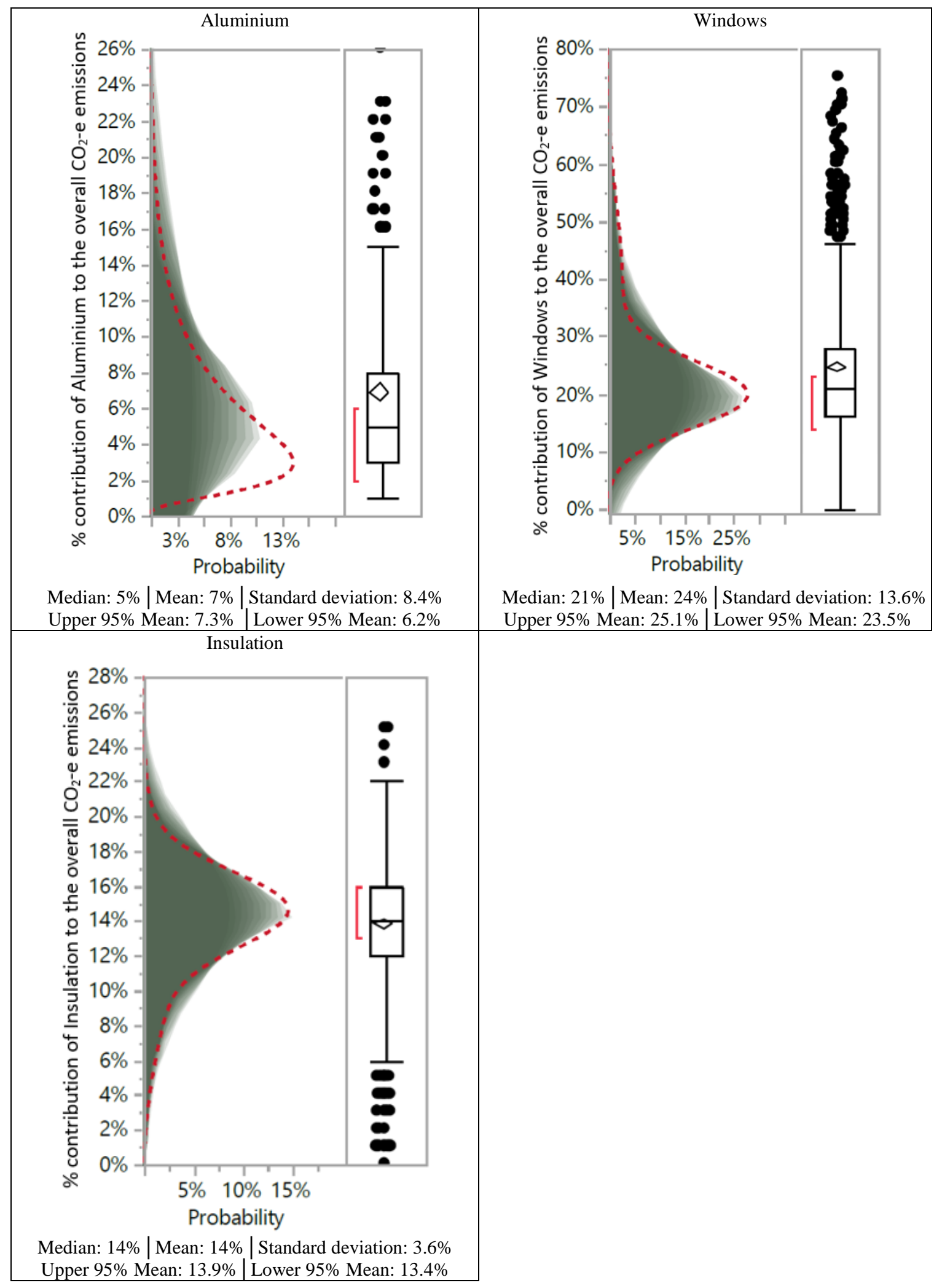

Figure 7. Probability distribution for the percentage contribution of Aluminium, Windows and Insulation to the overall embodied $\mathrm{CO}_{2}$-e emissions 


\subsection{Uncertainty associated with Solar PV Panels:}

377 The cumulative probability variation of output data showed that the solar PV panels had the 378 second highest impact on total embodied $\mathrm{CO}_{2}$-e emissions of the building. The uncertainty 379 analysis of output data showed that solar PV panels were responsible for $18 \%$ (mean value) of 380 total embodied $\mathrm{CO}_{2}$-e emissions of the building (as shown in Figure 8).

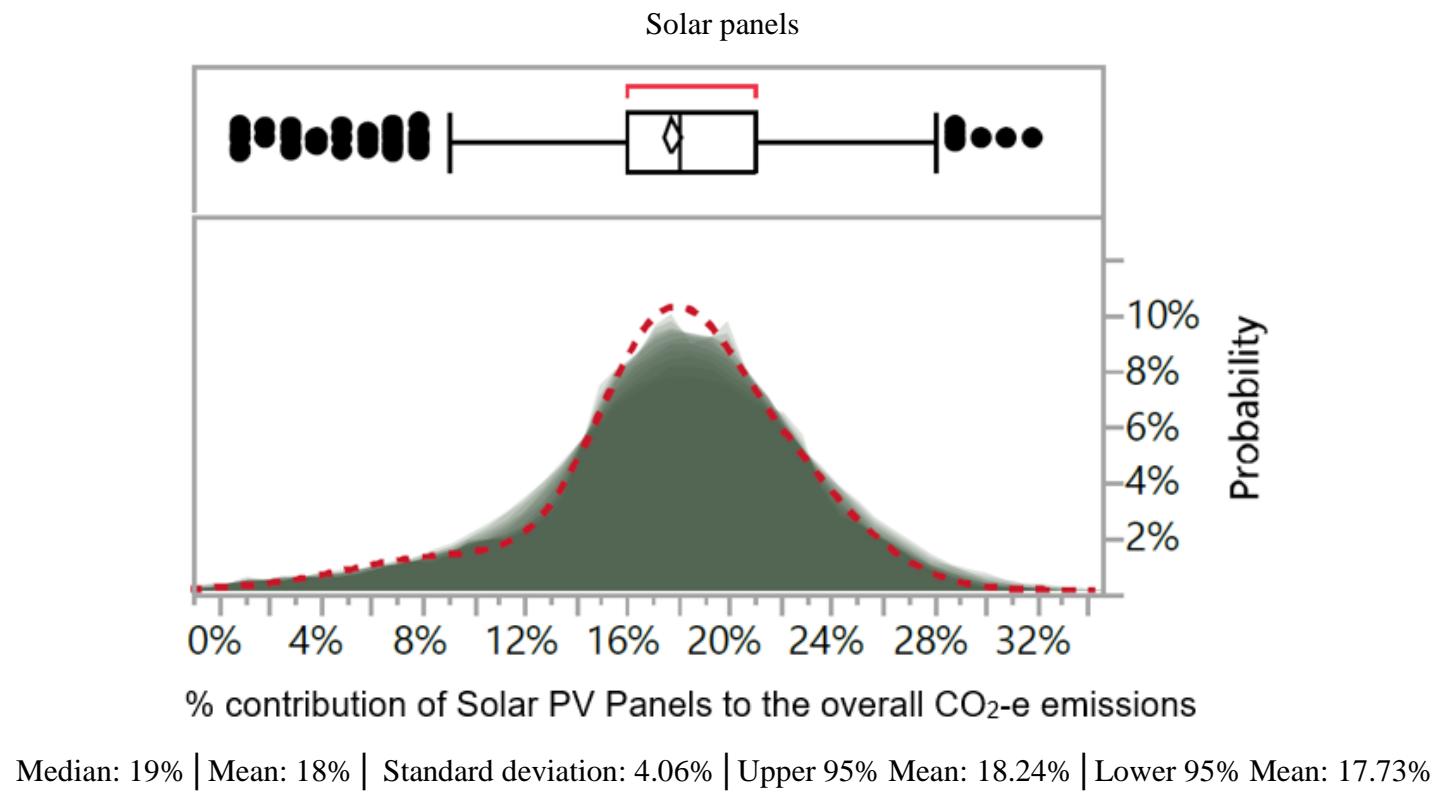

381

382

383

384

Figure 8. Probability distribution for the percentage contribution of solar PV panels to the overall embodied $\mathrm{CO}_{2}$-e emissions of the building

Similarly to the previous section, the variation of the results are largely due to differences in the inventory databases and the lifetime of PV solar panels. The embodied $\mathrm{CO}_{2}-\mathrm{e}$ emissions related to the production of the PV system ranged from 12 to $569 \mathrm{~g} \mathrm{CO}_{2}$-e/kWh (Wong et al. 2016). The uncertainty related to the embodied $\mathrm{CO}_{2}$-e emissions coefficient has been affected due to the changes in efficiency of PV panel, levels of solar irradiation, technology associated with manufacturing of PV panel as well as the application of PV panel (residential, commercial or power plant) (Kim et al. 2014; Wong et al. 2016). The results of Sherwani et al. (2010) study on LCA of commonly used solar PV showed that carbon emissions of panels have been 
392 dependent on type of solar cell, for instance, amorphous solar cells (thin film modules) emit 393 less carbon energy while its efficiency was lower than other cells (mono-crystalline and poly394 crystalline ).

395 Additionally, it was found that the overall embodied $\mathrm{CO}_{2}$-e emissions of PV system was 396 significantly influenced (up to $50 \%$ ) by having a lower lifespan in comparison with the 397 assumed building life and therefore they require maintenance and refurbishment after a certain 398 period (every 25 years) (Ma et al. 2014).

\section{4.4 Uncertainty associated with Concrete materials}

400 The difference in the amount of embodied $\mathrm{CO}_{2}$-e emissions for two types of concrete that were 401 used in the building was quantified. The mean embodied carbon emissions associated with the 402 concrete used in the structural components that had higher cement substitution (Case a: $40 \mathrm{MPa}$ 403 with $60 \%$ Blast Furnace Slag-in Figure 9) were $7 \%$ of the overall $\mathrm{CO}_{2}$-e emissions of the 404 building. On the other hand, the mean embodied carbon emissions for the concrete used in the 405 walls and floors systems with a lower cement substitution material (Case b: 40 MPa with 30\% 406 Blast Furnace Slag-in Figure 9) were $10 \%$ of the total $\mathrm{CO}_{2}$-e emissions; 3\% higher than the

407 Case a. The overall magnitude impacts of concrete (for both cases) in terms of $\mathrm{CO}_{2}$-e emissions 408 ranged from $4 \%$ to $28 \%$ (assuming a $95 \%$ confidence interval) of the total $\mathrm{CO}_{2}$-e emissions 409 from the building (Figure 9). 


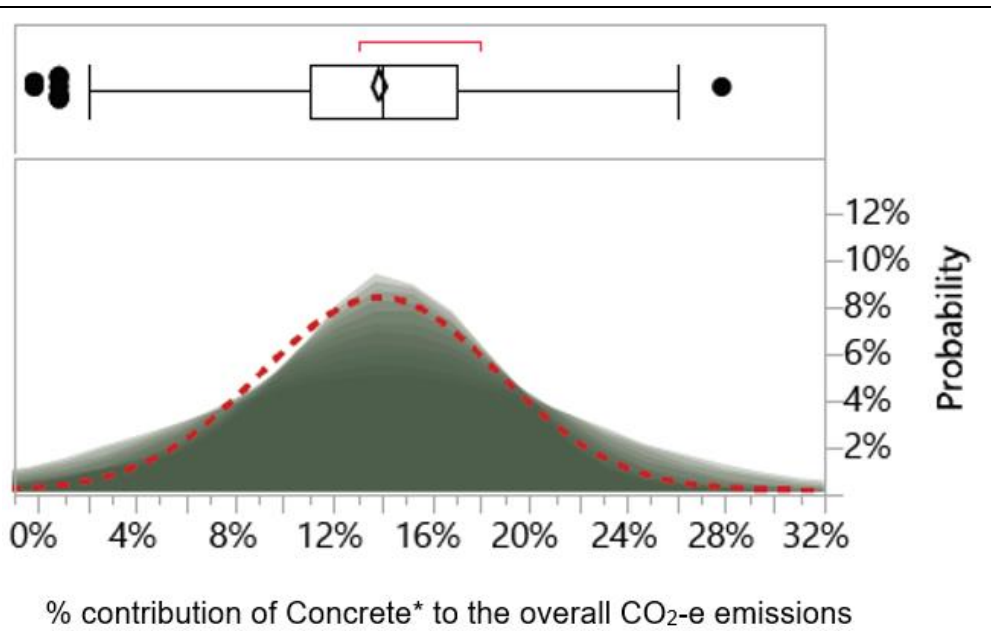

Median: 14\% | Mean: 14\% | Standard deviation: 4.85\% | Upper 95\% Mean: 14.4\% | Lower 95\% Mean: 13.8\% * Concrete includes a combination of Structural Concrete (40 MPa;60\% Blast Furnace Slag) and Concrete for Walls, floor topping (40 MPa,30\% Blast Furnace Slag).

\section{Concrete (a)}

Structural; $40 \mathrm{MPa} ; 60 \%$ BFS*

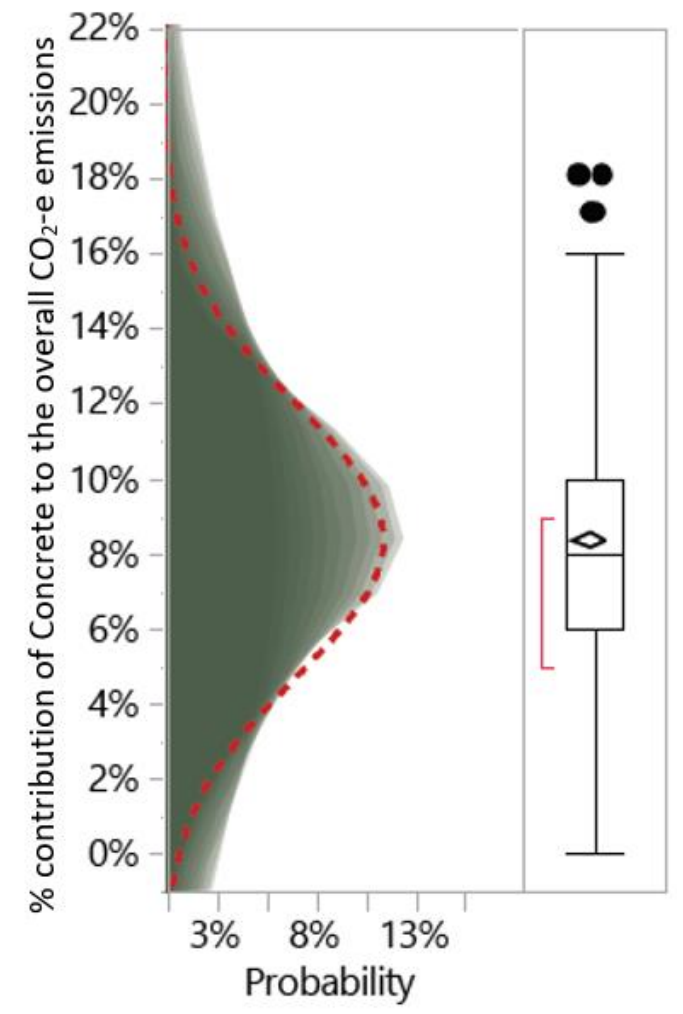

Median: 7\% | Mean: 7\% | Standard deviation: 3.03\% Upper 95\% Mean: $7.16 \%$ | Lower 95\% Mean: 6.78\% *BFS: Blast Furnace Slag
Concrete (b)

Walls, floor topping $40 \mathrm{MPa}, 30 \%$ BFS*

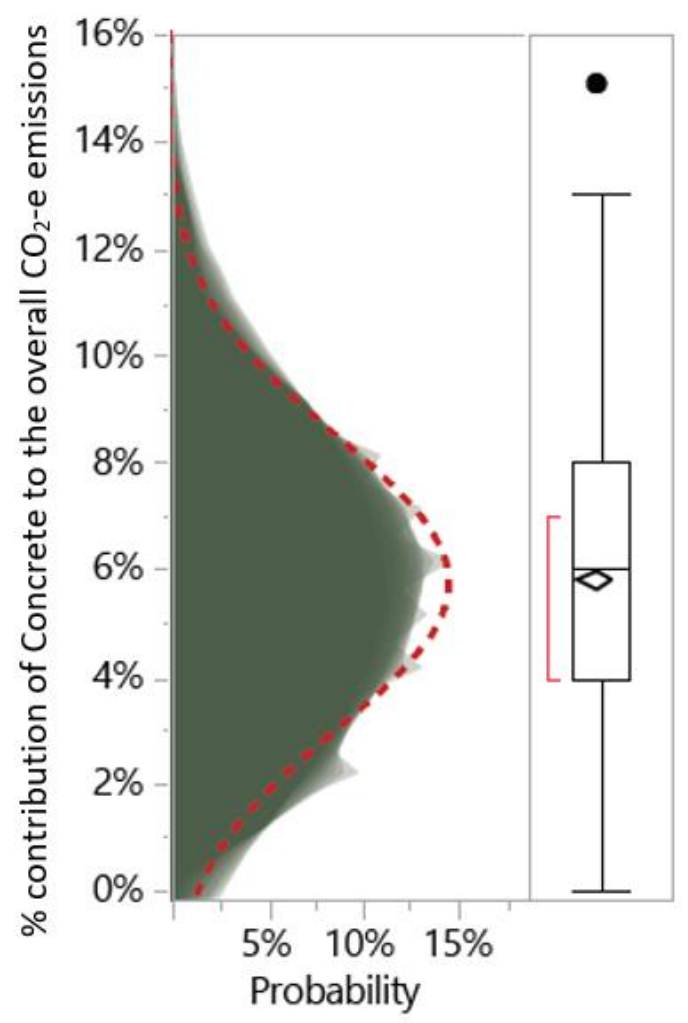

Median: 10\% | Mean: 10\% | Standard deviation: $3.85 \%$ Upper 95\% Mean: 10.32\% | Lower 95\% Mean: 9.84\% 
413 The resulted concrete greenhouse emissions were mainly influenced by the variations across

414 the different inventory databases. These recorded variations in embodied $\mathrm{CO}_{2}$-e emissions are

415 due to the different methods of analysis used in the different databases, the source of data and

416 quality of input data (related to the upstream process) in the calculation (Illankoon et al. 2018;

417 Le, Khoa N et al. 2018; Robati et al. 2016).

418 For instance, the embodied $\mathrm{CO}_{2}$-e emissions values across Alcorn, Crawford, eTool, ICE and 419 AusLCI databases vary from 75 to $600 \mathrm{~kg} \mathrm{CO}_{2}-\mathrm{e} / \mathrm{m}^{3}$ (Robati et al. 2016). The embodied $\mathrm{CO}_{2}$ 420 e emissions from transportation and lifetime of concrete contributed to $10 \%$ of the total impact 421 of concrete over the lifetime of the building.

\subsection{Impact of the building's lifetime on whole-life embodied carbon emissions.}

423 The total life cycle assessment considers the whole-life of the building, from pre-use process, 424 operational phase and end of life. Through the use of on-site renewable generation 425 technologies, the SBRC produces more energy than it consumes over an annual operational 426 phase (as shown in Figure 10), making the SBRC building a net exporter of energy to the grid 427 over a year. This trend in energy consumption points out the significance of embodied carbon 428 emission in a net-zero building and raises a question about the impact of assumption made 429 regarding the building's life, as disused below. 


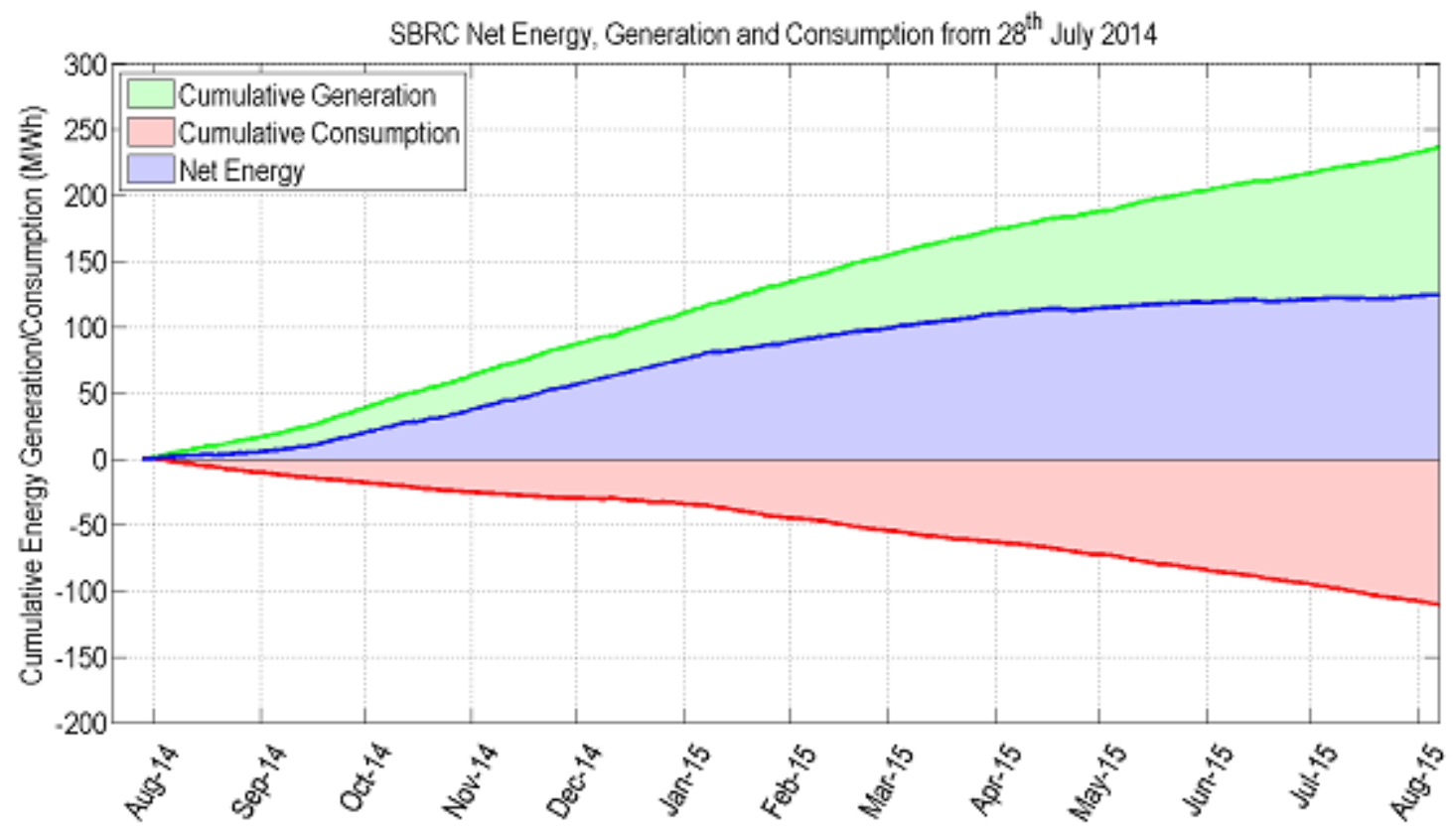

Figure 10. SBRC cumulative energy performance

433 The results of uncertainty analysis in Figure 11 show that the assumed length of a building's

434 life could have a considerable effect on the overall results of embodied $\mathrm{CO}_{2}$-e emissions 435 calculation, the other variable remained the same (similar to the previous sections). The results 436 show that by increasing the building lifetime from 50 to 150 years, the mean overall 437 environmental impact of the building in terms of $\mathrm{CO}_{2}$-e emissions will be increased by $185 \%$ 438 (from 3,828 to 10,936 tCO2-e), as shown in Figure 11. This is mainly caused by the increased 439 impact of the operational phase of the building as a result of replacing materials and interior 440 finishes. The probability trends of the output data were consistent across all five different 441 lifetime scenarios. However, it has to be mentioned that to fully understand and quantify the 442 uncertainty associated with products' lifetime requires considerations of the materials 443 durability, service conditions, materials properties, maintenance and occupants' behaviour 444 during the operational phase of the buildings. The ongoing developments in the durability of 445 construction materials could also reduce maintenance and replacement requirements. 


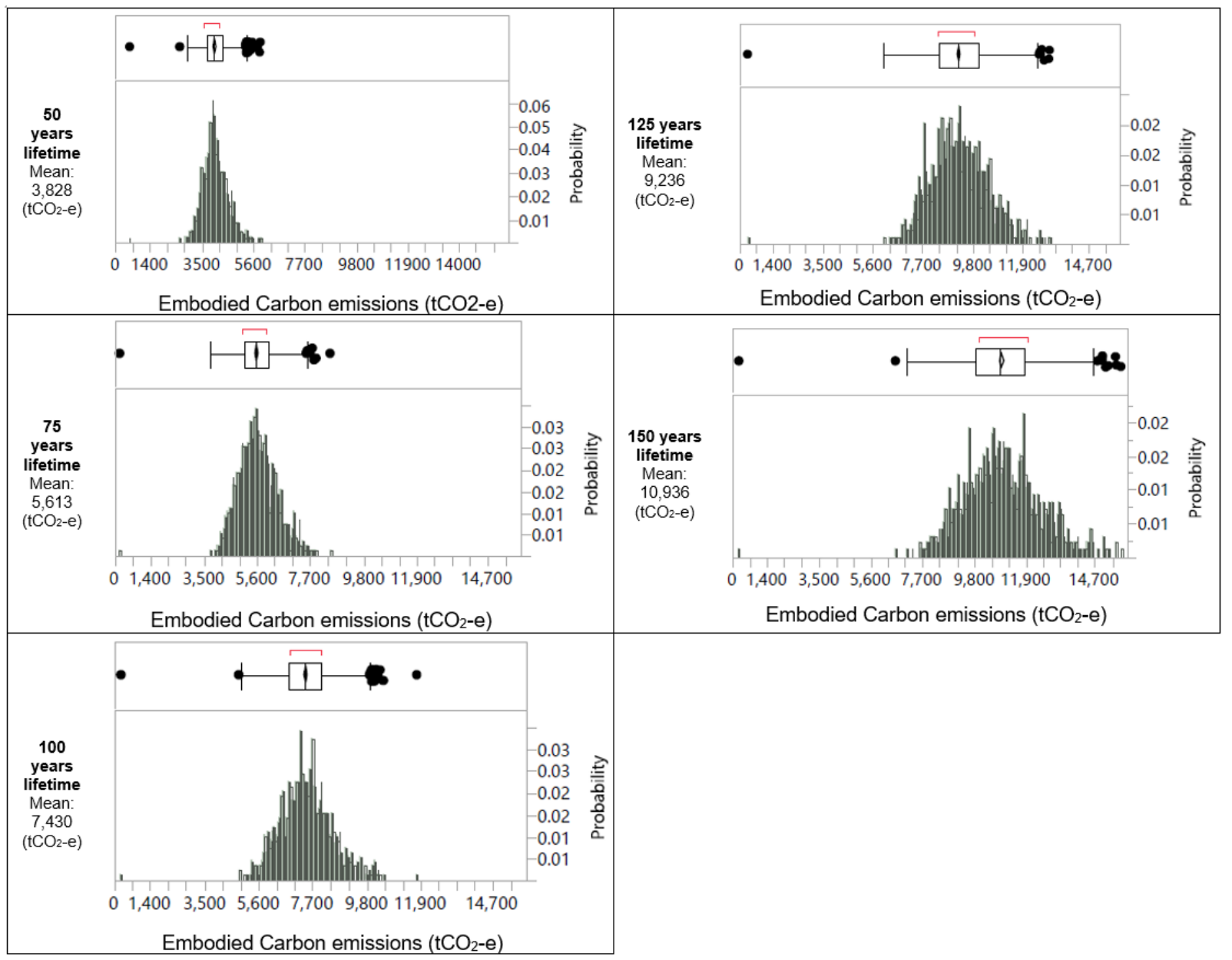

447 Figure 11. Impact of building's lifespan on the life cycle embodied $\mathrm{CO}_{2}$-e

\section{Conclusion}

449 A Monte Carlo simulation method was employed to predict the ranges of the embodied $\mathrm{CO}_{2}-\mathrm{e}$

450 emissions associated with a net-zero energy University building. The probability distributions

451 of the most influential building materials (input data) were obtained in order to estimate the

452 mean (expected) embodied $\mathrm{CO}_{2}$-e emissions value of each of the building materials. The

453 embodied carbon emissions associated with each input parameter was used into the Monte

454 Carlo simulation to produce the mass function for the whole life embodied carbon emission of

455 the building. The total embodied energy of the case study building was found to be highly

456 sensitive to input assumptions and varied by order of magnitude from lowest to highest possible

457 calculated value, using reasonable inputs from previously published research. The mean $\mathrm{CO}_{2}-$ 
e emissions value for the building was calculated at 3,828 $\mathrm{tCO}_{2}$-e, (with standard deviation of $\left.502 \mathrm{tCO}_{2}-\mathrm{e}\right)$. This study highlighted the contribution and variation of most carbon-intensive construction materials during the lifetime of the building. It was found that solar PV panels, double glazed windows with aluminium frame, concrete (two types of concrete) and insulation are the key parameters that should be given due attention. These four components contribute to $78 \%$ (mean contribution) of total $\mathrm{CO} 2$-e emissions of the building. Considering reasonable assumptions, the mean embodied $\mathrm{CO}_{2}$-e emissions impacts were estimated as $18 \%$ for Solar PV panel, 24\% for double glazed windows with aluminium frame, 14\% for Insulation, 7\% for Aluminium and $14 \%$ for concrete.

The ranges in these results were mainly due to differences in the carbon inventory datasets. For the solar PV panels and the windows, the assumed lifespan of the materials had a considerable impact on their overall embodied $\mathrm{CO}_{2}$-e emissions. Transporting materials to the site was a significant contributing factor to the embodied $\mathrm{CO}_{2}$ emissions for the cases of concrete and windows as these two components involved relatively high quantities and long distances, respectively. It was also noticed that the total embodied $\mathrm{CO}_{2}$-e emissions of the building were increased by assuming longer building lifetimes that ranged from 50 to 150 years. This study emphasises the need for considering uncertainties associated with LCA analysis to avoid misrepresentation of the final results at the decision-making processes.

476 The findings of this study can be used as a guideline for future comparison of environmental 477 impacts associated with buildings materials and systems. This work integrates the embodied $478 \mathrm{CO}_{2}$-e emissions associated with the building performance during its lifetime and highlights 479 the importance of ensuring appropriate input assumptions are employed in a life cycle 480 assessment. 
Akbarnezhad, A \& Xiao, J 2017, 'Estimation and Minimization of Embodied Carbon of Buildings: A Review', Buildings, vol. 7, no. 1, p. 5.

Alcorn, A 2003, Embodied energy and CO2 coefficients for NZ building materials, Centre for Building Performance Research, Wellington, New Zealand.

André, JC \& Lopes, DRJTIJoLCA 2012, 'On the use of possibility theory in uncertainty analysis of life cycle inventory', vol. 17 , no. 3, pp. 350-61.

AS3600 2009, Concrete structures, Standards Australia International Ltd, Sydney, Australia.

Asdrubali, F, Baldassarri, C \& Fthenakis, V 2013, 'Life cycle analysis in the construction sector: Guiding the optimization of conventional Italian buildings', Energy and Buildings, vol. 64, no. 0 , pp. 73-89.

Asif, M, Muneer, T \& Kelley, R 2007, 'Life cycle assessment: A case study of a dwelling home in Scotland', Building and Environment, vol. 42, no. 3, pp. 1391-4.

AusLCI 2016, The Australian national life cycle inventory database, http://alcas.asn.au/.

Aye, L, Ngo, T, Crawford, RH, Gammampila, R \& Mendis, P 2012, 'Life cycle greenhouse gas emissions and energy analysis of prefabricated reusable building modules', Energy and Buildings, vol. 47, pp. 159-68.

Beltran, AM, Heijungs, R, Guinée, J \& Tukker, A 2016, 'A pseudo-statistical approach to treat choice uncertainty: the example of partitioning allocation methods', The International Journal of Life Cycle Assessment, vol. 21, no. 2, pp. 252-64.

Berge, B 2009, The ecology of building materials, Routledge.

Bisinella, V, Conradsen, K, Christensen, TH \& Astrup, TF 2016, 'A global approach for sparse representation of uncertainty in Life Cycle Assessments of waste management systems', The International Journal of Life Cycle Assessment, vol. 21, no. 3, pp. 378-94.

Bojacá, CR \& Schrevens, E 2010, 'Parameter uncertainty in LCA: stochastic sampling under correlation', The International Journal of Life Cycle Assessment, vol. 15, no. 3, pp. 238-46.

BPIC 2014, Building product life cycle inventory, Building Products Innovation Council, viewed 8/8/2017, <http://www.bpic.asn.au/>.

Cabeza, LF, Rincón, L, Vilariño, V, Pérez, G \& Castell, A 2014, 'Life cycle assessment (LCA) and life cycle energy analysis (LCEA) of buildings and the building sector: A review', Renewable and Sustainable Energy Reviews, vol. 29, pp. 394-416.

Catherine, DW, Frances, Y, Duncan, C, Andrea, C, Seif, HA \& John, O 2016, 'Material quantities and embodied carbon dioxide in structures', Proceedings of the Institution of Civil Engineers Engineering Sustainability.

Combet, G 2012, Securing a clean energy future : implementing the Australian Government's climate change plan, The Australian Government Department of Climate Change and Energy Efficiency, Canberra, Australia, ISBN 978-1-922003-44-7.

Crawford, R 2011, Life cycle assessment in the built environment, Spon Press, New York.

Crawford, RH 2013, 'Post-occupancy life cycle energy assessment of a residential building in Australia', Architectural Science Review, vol. 57, no. 2, pp. 114-24.

Davies, D \& Trabucco, D 2018, 'Embodied Carbon of Tall Buildings: Specific Challenges', in Embodied Carbon in Buildings, Springer, pp. 341-64.

Ding, G 2004, 'The development of a multi-criteria approach for the measurement of sustainable performance for built projects and facilities', Doctor of Philosophy thesis, University of Technology Sydney.

Ding, G 2008, 'Sustainable construction-The role of environmental assessment tools', Journal of Environmental Management, vol. 86, no. 3, pp. 451-64.

Ding, G 2014, 'Life cycle assessment (LCA) of sustainable building materials: an overview', pp. 3862.

Dixit, MK, Fernández-Solís, JL, Lavy, S \& Culp, CH 2010, 'Identification of parameters for embodied energy measurement: A literature review', Energy and Buildings, vol. 42, no. 8, pp. 1238-47. 
Dowdell, D, Berg, B, Marston, N, Shaw, P, Burgess, J, Roberti, J \& White, B 2016, New Zealand wholebuilding whole-of-life framework: Development of datasheets to support building life cycle assessment, BRANZ, Porirua.

Egilmez, G, Gumus, S, Kucukvar, M \& Tatari, OJJocp 2016, ‘A fuzzy data envelopment analysis framework for dealing with uncertainty impacts of input-output life cycle assessment models on eco-efficiency assessment', vol. 129, pp. 622-36.

EN15978 2011, Sustainability of construction works : assessment of environmental performance of buildings : calculation method, British Standards Institution, United Kingdom.

eTool 2014, Life cycle assessment online tool, viewed 23/6/2015, <http://etoolglobal.com/>.

Farrance, I \& Frenkel, R 2014, 'Uncertainty in measurement: a review of Monte Carlo simulation using Microsoft Excel for the calculation of uncertainties through functional relationships, including uncertainties in empirically derived constants', The Clinical Biochemist Reviews, vol. 35, no. 1, p. 37.

Franzoni, E 2011, 'Materials selection for green buildings: which tools for engineers and architects?', Procedia Engineering, vol. 21, pp. 883-90.

Furuta, H, Frangopol, DM \& Akiyama, M 2014, Life-cycle of structural systems: Design, assessment, maintenance and management, CRC Press.

Gantner, J, Fawcett, W \& Ellingham, I 2018, 'Probabilistic Approaches to the Measurement of Embodied Carbon in Buildings', in F Pomponi, C De Wolf \& A Moncaster (eds), Embodied Carbon in Buildings: Measurement, Management, and Mitigation, Springer International Publishing, Cham, pp. 23-50.

GBCA 2017, GREEN STAR PROJECT DIRECTORY, GREEN BUILDING COUNCIL AUSTRALIA (GBCA), viewed 11/1/2017, <http://www.gbca.org.au/project-directory.asp\#31315>.

González, MJ \& García Navarro, J 2006, 'Assessment of the decrease of CO2 emissions in the construction field through the selection of materials: Practical case study of three houses of low environmental impact', Building and Environment, vol. 41, no. 7, pp. 902-9.

Grant, A, Ries, R \& Thompson, C 2016, 'Quantitative approaches in life cycle assessment-part 2multivariate correlation and regression analysis', The International Journal of Life Cycle Assessment, vol. 21, no. 6, pp. 912-9.

Hammad, AWA, Akbarnezhad, A \& Oldfield, P 2018, 'Optimising embodied carbon and U-value in load bearing walls: A mathematical bi-objective mixed integer programming approach', Energy and Buildings, vol. 174, pp. 657-71.

Hammond, G, Jones, C, Lowrie, F \& Tse, P 2011, Embodied carbon: the inventory of carbon and energy (ICE), BSRIA.

Heiselberg, P, Brohus, H, Hesselholt, A, Rasmussen, H, Seinre, E \& Thomas, S 2009, 'Application of sensitivity analysis in design of sustainable buildings', Renewable Energy, vol. 34, no. 9, pp. 2030-6.

Hester, J, Miller, TR, Gregory, J \& Kirchain, R 2018, 'Actionable insights with less data: guiding early building design decisions with streamlined probabilistic life cycle assessment', The International Journal of Life Cycle Assessment.

Hong, J, Shen, GQ, Peng, Y, Feng, Y \& Mao, CJJocp 2017, 'Reprint of: Uncertainty analysis for measuring greenhouse gas emissions in the building construction phase: a case study in China', vol. 163, pp. S420-S32.

Hong, J, Shen, GQ \& Tang, M 2018, 'Current Approaches for Embodied Carbon Assessment of Buildings in China: An Overview', in F Pomponi, C De Wolf \& A Moncaster (eds), Embodied Carbon in Buildings: Measurement, Management, and Mitigation, Springer International Publishing, Cham, pp. 417-42.

Hoxha, E, Habert, G, Chevalier, J, Bazzana, M \& Le Roy, RJJocp 2014, 'Method to analyse the contribution of material's sensitivity in buildings' environmental impact', vol. 66, pp. 54-64.

Huang, Z, Ding, X, Sun, H \& Liu, S 2010, 'Identification of main influencing factors of life cycle CO2 emissions from the integrated steelworks using sensitivity analysis', Journal of Cleaner Production, vol. 18, no. 10-11, pp. 1052-8. 
Illankoon, IMCS, Tam, VWY, Le, KN \& Wang, JY 2018, 'Life cycle costing for obtaining concrete credits in green star rating system in Australia', Journal of Cleaner Production, vol. 172, pp. 4212-9.

Inyim, P, Zhu, Y \& Orabi, W 2016, 'Analysis of Time, Cost, and Environmental Impact Relationships at the Building-Material Level', Journal of Management in Engineering, vol. 32, no. 4, p. 04016005.

ISO14040 2006, Environmental management-life cycle assessment-principles and framework, International Organization for Standardization, Switzerland.

Kim, B-j, Lee, J-y, Kim, K-h \& Hur, T 2014, 'Evaluation of the environmental performance of sc-Si and mc-Si PV systems in Korea', Solar Energy, vol. 99, pp. 100-14.

Langston, YL \& Langston, CA 2008, 'Reliability of building embodied energy modelling: an analysis of 30 Melbourne case studies', Construction Management and Economics, vol. 26, no. 2, pp. 147-60.

Le, KN, Tam, VW, Tran, CN, Wang, J \& Goggins, BJIToEM 2018, 'Life-Cycle Greenhouse Gas Emission Analyses for Green Star's Concrete Credits in Australia', no. 99, pp. 1-13.

Le, KN, Tran, CNN \& Tam, VWY 2018, 'Life-cycle greenhouse-gas emissions assessment: An Australian commercial building perspective', Journal of Cleaner Production, vol. 199, pp. 23647.

Lehne, J \& Preston, F 2018, Making Concrete Change: Innovation in Low-carbon Cement and Concrete, Chatham House, London.

Lloyd, SM \& Ries, RJJoIE 2007, 'Characterizing, propagating, and analyzing uncertainty in life-cycle assessment: A survey of quantitative approaches', vol. 11, no. 1, pp. 161-79.

Ma, T, Yang, H \& Lu, L 2014, 'A feasibility study of a stand-alone hybrid solar-wind-battery system for a remote island', Applied Energy, vol. 121, pp. 149-58.

Macintosh, A 2007, Climate change and Australian coastal shipping, Australia Institute.

Mendoza Beltran, A, Prado, V, Font Vivanco, D, Henriksson, PJ, Guinée, JB \& Heijungs, R 2018, 'Quantified Uncertainties in Comparative Life Cycle Assessment: What Can Be Concluded?', Environmental science \& technology, vol. 52, no. 4, pp. 2152-61.

Mendoza Beltran, MA, Pomponi, F, Guinée, JB \& Heijungs, R 2018, 'Uncertainty Analysis in Embodied Carbon Assessments: What Are the Implications of Its Omission?', in F Pomponi, C De Wolf \& A Moncaster (eds), Embodied Carbon in Buildings: Measurement, Management, and Mitigation, Springer International Publishing, Cham, pp. 3-21.

Miller, SA, Moysey, S, Sharp, B \& Alfaro, JJJoIE 2013, 'A stochastic approach to model dynamic systems in life cycle assessment', vol. 17, no. 3, pp. 352-62.

Mokhlesian, S \& Holmén, M 2012, 'Business model changes and green construction processes', Construction Management and Economics, vol. 30, no. 9, pp. 761-75.

Moussavi Nadoushani, ZS \& Akbarnezhad, A 2015, 'Effects of structural system on the life cycle carbon footprint of buildings', Energy and Buildings, vol. 102, pp. 337-46.

Oke, AE \& Aigbavboa, CO 2017, Sustainable value management for construction projects, Springer.

Oldfield, P 2012, 'Embodied carbon and high-rise', in Proceedings of CTBUH 9th World Congress, Shanghai, China, pp. 19-21.

Ortiz, O, Castells, F \& Sonnemann, G 2009, 'Sustainability in the construction industry: A review of recent developments based on LCA', Construction and Building Materials, vol. 23, no. 1, pp. 28-39.

Paolo, T, Jeremy, G, Elsa, O, Randa, G \& Randolph, K 2018, 'Streamlining the Life Cycle Assessment of Buildings by Structured Under-Specification and Probabilistic Triage', Journal of Industrial Ecology.

Peña-Mora, F, Ahn, C, Golparvar-Fard, M, Hajibabai, L, Shiftehfar, S, An, S \& Aziz, Z 2009, 'A framework for managing emissions from construction processes', in Proc., Int. Conf. \& Workshop on Sustainable Green Bldg. Design \& Construction, National Science Foundation.

Poinssot, C, Bourg, S, Ouvrier, N, Combernoux, N, Rostaing, C, Vargas-Gonzalez, M \& Bruno, J 2014, 'Assessment of the environmental footprint of nuclear energy systems. Comparison between closed and open fuel cycles', Energy, vol. 69, pp. 199-211. 
Pomponi, F, D'Amico, B \& Moncaster, AM 2017, 'A Method to Facilitate Uncertainty Analysis in LCAs of Buildings', vol. 10, no. 4, p. 524.

Pomponi, F \& Moncaster, A 2016, 'Embodied carbon mitigation and reduction in the built environment-What does the evidence say?', Journal of Environmental Management, vol. 181, pp. 687-700.

Ramesh, T, Prakash, R \& Shukla, KK 2010, 'Life cycle energy analysis of buildings: An overview', Energy and Buildings, vol. 42, no. 10, pp. 1592-600.

Richman, R, Pasqualini, P \& Kirsh, A 2009, 'Life-Cycle analysis of roofing insulation levels for cold storage buildings', Journal of Architectural Engineering, vol. 15, no. 2, pp. 55-61.

Robati, M, Kokogiannakis, G \& McCarthy, TJ 2017, 'Impact of structural design solutions on the energy and thermal performance of an Australian office building', Building and Environment, vol. 124 , pp. 258-82.

Robati, M, McCarthy, TJ \& Kokogiannakis, G 2016, 'Incorporating environmental evaluation and thermal properties of concrete mix designs', Construction and Building Materials, vol. 128, pp. 422-35.

Robati, M, McCarthy, TJ \& Kokogiannakis, G 2018, 'Integrated life cycle cost method for sustainable structural design by focusing on a benchmark office building in Australia', Energy and Buildings.

Ruuska, AP \& Häkkinen, TM 2015, 'The significance of various factors for GHG emissions of buildings', International Journal of Sustainable Engineering, vol. 8, no. 4-5, pp. 317-30.

Saghafi, MD \& Teshnizi, ZSH 2011, 'Recycling value of building materials in building assessment systems', Energy and Buildings, vol. 43, no. 11, pp. 3181-8.

Sartori, I \& Hestnes, AG 2007, 'Energy use in the life cycle of conventional and low-energy buildings: A review article', Energy and Buildings, vol. 39, no. 3, pp. 249-57.

Sharma, A, Saxena, A, Sethi, M \& Shree, V 2011, 'Life cycle assessment of buildings: a review', Renewable and Sustainable Energy Reviews, vol. 15, no. 1, pp. 871-5.

Sherwani, AF, Usmani, JA \& Varun 2010, 'Life cycle assessment of solar PV based electricity generation systems: A review', Renewable and Sustainable Energy Reviews, vol. 14, no. 1, pp. 540-4.

Silva, AS \& Ghisi, E 2014, 'Uncertainty analysis of user behaviour and physical parameters in residential building performance simulation', Energy and Buildings, vol. 76, pp. 381-91.

Stephan, A \& Crawford, RH 2014, 'A multi-scale life-cycle energy and greenhouse-gas emissions analysis model for residential buildings', Architectural Science Review, vol. 57, no. 1, pp. 3948.

Taborianski, VM \& Prado, RT 2004, 'Comparative evaluation of the contribution of residential water heating systems to the variation of greenhouse gases stock in the atmosphere', Building and Environment, vol. 39, no. 6, pp. 645-52.

Tam, WYV, Le, KN, Tran, CNN \& Wang, JY 2018, 'A review on contemporary computational programs for Building's life-cycle energy consumption and greenhouse-gas emissions assessment: An empirical study in Australia', Journal of Cleaner Production, vol. 172, pp. 4220-30.

Tecchio, P, Gregory, J, Ghattas, R \& Kirchain, R 2018, 'Structured Under-Specification of Life Cycle Impact Assessment Data for Building Assemblies', Journal of Industrial Ecology.

Thormark, C 2006, 'The effect of material choice on the total energy need and recycling potential of a building', Building and Environment, vol. 41, no. 8, pp. 1019-26.

Wang, E \& Shen, ZJJocp 2013, 'A hybrid Data Quality Indicator and statistical method for improving uncertainty analysis in LCA of complex system-application to the whole-building embodied energy analysis', vol. 43, pp. 166-73.

Wong, J, Royapoor, M \& Chan, C 2016, 'Review of life cycle analyses and embodied energy requirements of single-crystalline and multi-crystalline silicon photovoltaic systems', Renewable and Sustainable Energy Reviews, vol. 58, pp. 608-18. 
688

689

690

691

692

693
Ximenes, FA \& Grant, T 2013, 'Quantifying the greenhouse benefits of the use of wood products in two popular house designs in Sydney, Australia', The International Journal of Life Cycle Assessment, vol. 18, no. 4, pp. 891-908.

Yu, M, Wiedmann, T, Crawford, R \& Tait, C 2017, 'The Carbon Footprint of Australia's Construction Sector', Procedia Engineering, vol. 180, pp. 211-20. 